\title{
Sourcing Obsidian from Late Neolithic Sites on the Great Hungarian Plain: Preliminary p-XRF Compositional Results and the Socio-Cultural Implications
}

\author{
Danielle J. Riebe ${ }^{\mathrm{a}^{*}}$ \\ ${ }^{a}$ The Field Museum of Natural History, 1400 S. Lake Shore Drive, Chicago, IL 60605, USA
}

\section{ARTICLE INFO}

\section{Article history:}

Received: $23^{\text {rd }}$ March 2019

Accepted: $18^{\text {th }}$ November 2019

DOI: http://dx.doi.org/ 10.24916/iansa.2019.2.1

Key words:

P-XRF Analysis

obsidian sourcing

prehistoric European archaeology

patterns of exploitation

socio-cultural boundaries

\begin{abstract}
A B S TR A C T
Significant archaeological research has been conducted on chipped stone tools recovered from prehistoric sites throughout Eastern Europe and the Balkans. The limited number of obsidian geological sources in the region, combined with the relatively homogeneous nature of obsidian and the increased use of new techniques for conducting compositional analysis in the field, has facilitated an accurate sourcing of obsidian artefacts from sites in the region. This article presents the compositional results of 203 obsidian artefacts recovered from seven Late Neolithic (5,000-4,500 BCE) sites from the Great Hungarian Plain. Compositional results of the archaeological specimens obtained with a Bruker portable X-ray fluorescence device ( $\mathrm{p}$-XRF) were compared with obsidian geological compositional data to determine artefact provenance. By sourcing the obsidian chipped stone tools, it is possible to reconstruct prehistoric patterns of exploitation/exchange and to note how these patterns vary throughout the Plain. The results illustrate that the majority of the studied artefacts originated from the Carpathian 1 source and only a limited number of samples came from the Carpathian 2E and Carpathian 2T sources. Based on this preliminary study, the variation in geological source exploitation may be linked to socio-cultural practices that differentiated the Tisza and Herpály archaeological units during the Late Neolithic.
\end{abstract}

\section{Introduction}

Chipped stone tool analysis is an essential aspect of prehistoric archaeological research throughout Europe, especially in regard to reconstructing developments in technology (see Kertész, 1994; Kozłowski, 2001; Perlès, 1987; 1990; Voytek, 1986), dietary and subsistence practices (see Eichmann, 2004; Kertész, 2003), and socio-economic systems of exchange (see Biró, 1998a; 2006; Cann and Renfrew, 1964; Renfrew et al., 1965; Starnini and Voytek, 2012; Torrence, 1986; Tykot, 2002a). Intensive studies on chipped stone tools from Neolithic sites throughout the Great Hungarian Plain have been used to understand individual site use (see Erdélyi-Bácskay, 2007; Starnini, 1994; Starnini and Szakmány, 1998; Starnini et al., 2007), and until more recently, fewer studies focused on synthesizing these results

*Corresponding author. E-mail: driebe@fieldmuseum.org to model chipped stone tool variation at the regional scale (see Biagi and Starnini, 2013; Biró, 1984; 1987; 1998a; 1998b; Kovács, 2013). Moreover, ascertaining provenance of chipped stone tools in the region has been traditionally determined through macroscopic analysis (see Biró, 1984; 1987; 1998a; 1998b; Erdélyi-Bácskay, 2007; Kertész, 1994; Kovács, 2013; Starnini, 1994). However, when dealing with a very homogenous material that has a large visual spectrum, such as obsidian, visual analysis can be misleading, which in turn can result in misinterpretations regarding material access, acquisition, and exchange (see Braswell et al., 2000; Moholy-Nagy, 2003; Tykot, 2002b).

Since the 1970s, compositional studies on Carpathian obsidian sources have made it possible to geochemically differentiate the sources (Biagi et al., 2007; Glascock et al., 2015; Kasztovszky and Biró, 2006; Kasztovszky et al., 2019; Kasztovszky et al., 2014; Kasztovszky et al., 2008; Oddone et al., 1999; Riebe, 2016; Rosania et al., 2008; Williams and 


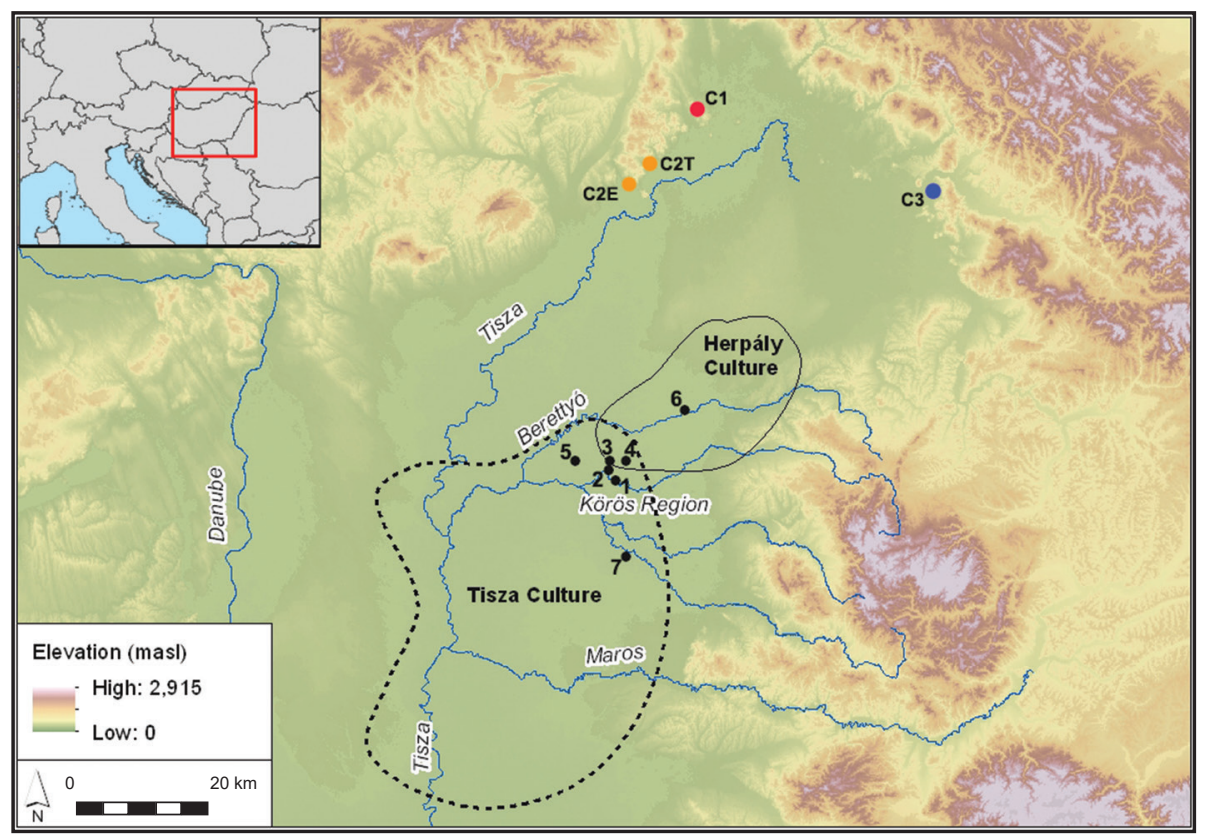

Figure 1. The Great Hungarian Plain with the nearby obsidian sources marked (Carpathian 1, Carpathian 2E, Carpathian 2T, and Carpathian 3), the Late Neolithic Herpály and Tisza cultural units demarcated, and the sites discussed in this article: 1) Vésztö-Mágor, 2) Szeghalom Kovácshalom, 3) Szeghalom-Várhely, 4) Csökmö-Káposztás Domb, 5) DévaványaRéhelyi Dülö, 6) Szentpéterszeg-Kovadomb 7) Gyula-Köztisztasági Vállalat.

Nandris, 1977; Williams Thorpe, 1978; Williams Thorpe et al., 1984). Four major sources are known in the region: Carpathian 1, Carpathian 2E, Carpathian 2T, and Carpathian 3 (Figure 1). While technology has significantly improved making it possible to inexpensively carry out compositional analysis in the field, p-XRF analysis of obsidian from prehistoric sites in Hungary has not been published previously. Therefore, the purpose of this paper is two-fold: firstly, to identify if different patterns of obsidian exploitation occurred during the Late Neolithic on the Great Hungarian Plain and if so, what social implications can be discerned from the variability. Secondly, while site-specific studies are essential, it is necessary to contextualize the sites and their assemblages within a regional framework. Through $\mathrm{p}-\mathrm{XRF}$ analysis of obsidian, it is possible to use the analytical results to begin reconstructing regional systems of interaction and model socio-cultural developments in the past. As part of an ongoing research project that is investigating the extent to which regional interactions impacts socio-cultural boundaries in the past, obsidian specimens from seven Late Neolithic sites located on the Great Hungarian Plain were selected for $\mathrm{p}$-XRF compositional analysis. The following results are preliminary in scope but illustrate the success of compositional analysis in reconstructing Late Neolithic regional interactions, including material exploitation and exchange, across the Great Hungarian Plain.

\section{The region}

During the Late Neolithic (5,000-4,500 BCE), there were three major archaeological units on the Great Hungarian Plain (Figure 1). The Csőszhalom archaeological unit was restricted to the far north along the northern part of the Tisza River, the Herpály archaeological unit was located in the middle of the Plain with sites predominantly situated along the Berettyó River, and in the southeastern part of the Plain was the Tisza archaeological unit with sites found along the Körös, Tisza, and Maros Rivers and their tributaries. There are a number of socio-cultural aspects that help to distinguish these archaeological units, chief among them being architectural style, subsistence practices, burial and ritual practices, and ceramic stylistic design (Kalicz and Raczky, 1987; Tálas and Raczky, 1987). While three archaeological units inhabited the region at this time, the focus of this study is on sites located in the Körös and Berettyó River Valleys. Between these two rivers, previous research has successfully modeled the presence of a strongly enforced boundary between the Herpály and Tisza cultural units (see Riebe, 2016).

In particular, one feature that both the Late Neolithic Tisza and Herpály sites have in common is their locational deficiency in regard to raw geological sources for creating chipped stone tools. Geographically, the Great Hungarian Plain is situated in the Carpathian Basin and is surrounded by a series of mountains that encircle the Plain. Exceptional research has been carried out on the lithic assemblages from many prehistoric sites in Hungary and while it is commonly accepted that exchange of some sort (i.e., down-the-line, direct procurement, and/or central redistribution) occurred in order for Late Neolithic inhabitants on the Plain to acquire geological materials for chipped stone tools, modeling this exchange has been limited in execution (Kovács, 2013; Riebe, 2016).

\section{Methods}

Early studies on obsidian in the region were ground breaking in terms of illustrating that compositional variation existed between different Carpathian sources. The initial success by scholars like O. Williams-Thorpe and J. Nandris (1977) in discerning obsidian source differentiation was 
likely tempered by the exorbitant cost associated with the geochemical analyses, resulting in limited compositional studies of obsidians in Hungary (see Constantinescu et al., 2002; Constantinescu et al., 2014; Kasztovszky and Biró, 2006; Kasztovszky et al., 2014; Kasztovszky et al., 2019; Williams-Thorpe et al., 1984). Instead, scholars relied on macroscopic analysis that depended on translucency and/or shades of black to differentiate the obsidian sources (Biró, 2006). In other cases, the analysis was simplified, and general material categories were utilized (i.e., "obsidian" as opposed to specific source categories such as Carpathian 1, Carpathian 2E, Carpathian 2T, or Carpathian 3) resulting in all obsidian sources and sub-sources being grouped together. However, because obsidian is so variable in terms of colour and translucency, the former method of analysis may easily have resulted in the misclassification of obsidian sources. Similarly, the latter method of analysis completely limits the researcher's interpretation and obscures any potential differences in source exploitation and/or access. To rectify this issue, it became necessary to find an analytical technique that could analyze the obsidian at a cost effective rate.
A solution to the obsidian sourcing issue was found in the portable X-ray fluorescence device. Beginning in the summer of 2013, a p-XRF device was brought to Hungary to analyze both archaeological and geological obsidian materials. Since this is a non-destructive technique, analysis causes no damage to the artefacts or geological samples. Additionally, analysis can be conducted in the country, thereby foregoing the necessity of permits to transport the samples abroad. As an initial project, the chipped stone assemblages from seven Late Neolithic sites that were designated as either archaeologically Herpály (Csökmö-Káposztás Domb, Szeghalom-Várhely, and Szentpéterszeg-Kovadomb) or archaeologically Tisza (Szeghalom-Kovácshalom, VésztőMágor, Dévaványa-Réhely-Dülő, and GyulaKöztisztasági Vállalat; Figure 1) were selected for analysis. The assemblages originate from both surface collections and excavations (Riebe, 2016). In addition to the archaeological materials, geological specimens representing the different obsidian sources were also analyzed. Dr. Katalin Biró at the Hungarian National Museum granted access to the Lithotheca collection, which contains samples of geological

Table 1. Geological samples analyzed from the Lithotheca Collection at the Hungarian National Museum.

\begin{tabular}{|c|c|c|c|}
\hline P-XRF ID & Source & Source abbreviation & Lithotheca inventory \\
\hline $\mathrm{V} 1$ & Vinicky & Carpathian 1 & L 2009.1.2 \\
\hline $\mathrm{V} 2$ & Vinicky & Carpathian 1 & L 2009.1.3 \\
\hline V3 & Vinicky & Carpathian 1 & L 2009.1.2/1 \\
\hline V4 & Vinicky & Carpathian 1 & L 2009.1.2/3 \\
\hline V5 & Vinicky & Carpathian 1 & L 2009.1.2/2 \\
\hline V6 & Vinicky & Carpathian 1 & L 2009.1.2/5 \\
\hline V7 & Vinicky & Carpathian 1 & L 2009.1.2/4 \\
\hline V11 & Vinicky & Carpathian 1 & L 86/189 \\
\hline V12 & Kasov & Carpathian 1 & L 86/188a \\
\hline V13 & Kasov & Carpathian 1 & L $86 / 187 a$ \\
\hline V14 & Kasov & Carpathian 1 & L $86 / 187 b$ \\
\hline V15 & Kasov & Carpathian 1 & L $86 / 188 b$ \\
\hline V16 & Vinicky & Carpathian 1 & L 86/191 \\
\hline V19 & Cejkov & Carpathian 1 & L $86 / 186$ \\
\hline L1 & CSSR Trebisov dist. Cejkov & Carpathian 1 & - \\
\hline $\mathrm{L} 2$ & Tokaj mts. Erdőbénye Setétes summit & Carpathian 2E & - \\
\hline L3 & Tokaj mts. Bodrogkeresztúr Tufabánya environs & Carpathian 2E & - \\
\hline L4 & Tokaj mts. Mád Kakas-hegy & Carpathian 2E & - \\
\hline L11 & Tokaj mts. Mád Kakas-hegy & Carpathian 2E & - \\
\hline L12 & Tokaj mts. Mád Kakas-hegy & Carpathian 2E & - \\
\hline V17 & Tolcsva Ranyi dulo (2T) & Carpathian $2 \mathrm{~T}$ & L $86 / 170 \mathrm{a}$ \\
\hline V18 & Tolcsva Ranyi dulo (2T) & Carpathian 2T & L $86 / 170 b$ \\
\hline V23 & Tolcsva collection pt. 1 (2T) & Carpathian $2 \mathrm{~T}$ & L 89/17 \\
\hline L5 & Tolcsva - west of $228,4 \mathrm{hp}$ & Carpathian 2T & - \\
\hline V8 & Tolcsva - ciroka arok $(2 \mathrm{~T})$ & Carpathian $2 \mathrm{~T}$ & L 2009.10.1 \\
\hline V22 & Rokoszovo - Transcarpathian Ukraine Hust & Carpathian 3 & L $86 / 272$ \\
\hline V9 & Rokoszovo & Carpathian 3 & L 2009.13.1 \\
\hline
\end{tabular}


sources from all over the world (see Biró and Dobosi, 1991; Biró et al., 2000). Samples from each of the four Carpathian sources were analyzed to construct geological source signatures (Table 1).

\section{Techniques}

ABrukerTRAcER III-SD on loan from the ElementalAnalysis Facility at the Field Museum of Natural History was utilized to analyze all samples in this study. This device is equipped with a Rh anode and for the purpose of analyzing obsidian materials, a filter composed of 12 millimeters of aluminum, 1 millimeter of titanium, and 6 millimeters of copper was inserted into the device. The Bruker was connected to a PC laptop and S1PXRF software utilized. A vacuum pump was not necessary for this project and because the pump was not employed it was possible to collect data for ten elements, including manganese $(\mathrm{Mn})$, iron $(\mathrm{Fe})$, zinc $(\mathrm{Zn})$, gallium $(\mathrm{Ga})$, thorium $(\mathrm{Th})$, rubidium $(\mathrm{Rb})$, strontium $(\mathrm{Sr})$, yttrium $(\mathrm{Y})$, zirconium $(\mathrm{Zr})$, and niobium $(\mathrm{Nb})$. Each sample was analyzed for 300 seconds at $40 \mathrm{kv}$ and $11 \mu \mathrm{A}$. In the S1PXRF software, the results were calibrated using a calibration file supplied by Bruker and developed with MURR that consists of 40 reference standards. The results were provided in parts-per-million (ppm) and were transformed to log-base 10 values prior to statistical processing using JMP software.

\section{Materials}

From the Lithotheca collections, twenty-seven geological obsidian specimens were analyzed representing the four obsidian geological sources: fifteen samples from Carpathian 1, five samples from Carpathian 2E, five samples from Carpathian 2T, and two samples from Carpathian 3. While Carpathian 3 is well known, evidence of its use beyond local exploitation has not been identified at prehistoric sites in Eastern Europe (Rácz, 2008; 2012; Rácz et al., 2016). Moreover, while some compositional studies have separated Carpathian 1 into two sources, Carpathian 1a and 1b (see Bačo et al., 2018; Burgert et al., 2017; Přichystal and Škrdla, 2014; Rosania and Baker, 2009; Rosania et al., 2008), this requires compositional techniques that measure more elements than the Bruker p-XRF. Specifically, Rosiana et al. (2008) conducted neutron activation analysis and relied on rubidium $(\mathrm{Rb})$, uranium $(\mathrm{U}), \mathrm{Sb}$ (antimony), and $\mathrm{Sc}$ (scandium) to differentiate Carpathian 1a and 1b. Of those

Table 2. Summary of chipped stone tools per site.

\begin{tabular}{|c|c|c|c|c|}
\hline Site/Material Type & Total Obsidian & Obsidian Analyzed w/P-XRF & Other Materials & Total \\
\hline Szentpéterszeg-Kovadomb & 12 & 12 & 40 & 52 \\
\hline Csökmő-Káposztás-Domb & 8 & 8 & 24 & 32 \\
\hline Dévaványa-Réhelyi-dűlő & 2 & 2 & 23 & 25 \\
\hline Szeghalom-Kovácshalom & 86 & 70 & 139 & 225 \\
\hline Szeghalom-Várhely & 77 & 74 & 74 & 151 \\
\hline Vésztő-Mágor & 19 & 19 & 47 & 66 \\
\hline Gyula-Köztisztasági Vállalat & 19 & 18 & 41 & 60 \\
\hline Total & 223 & 203 & 388 & 611 \\
\hline
\end{tabular}

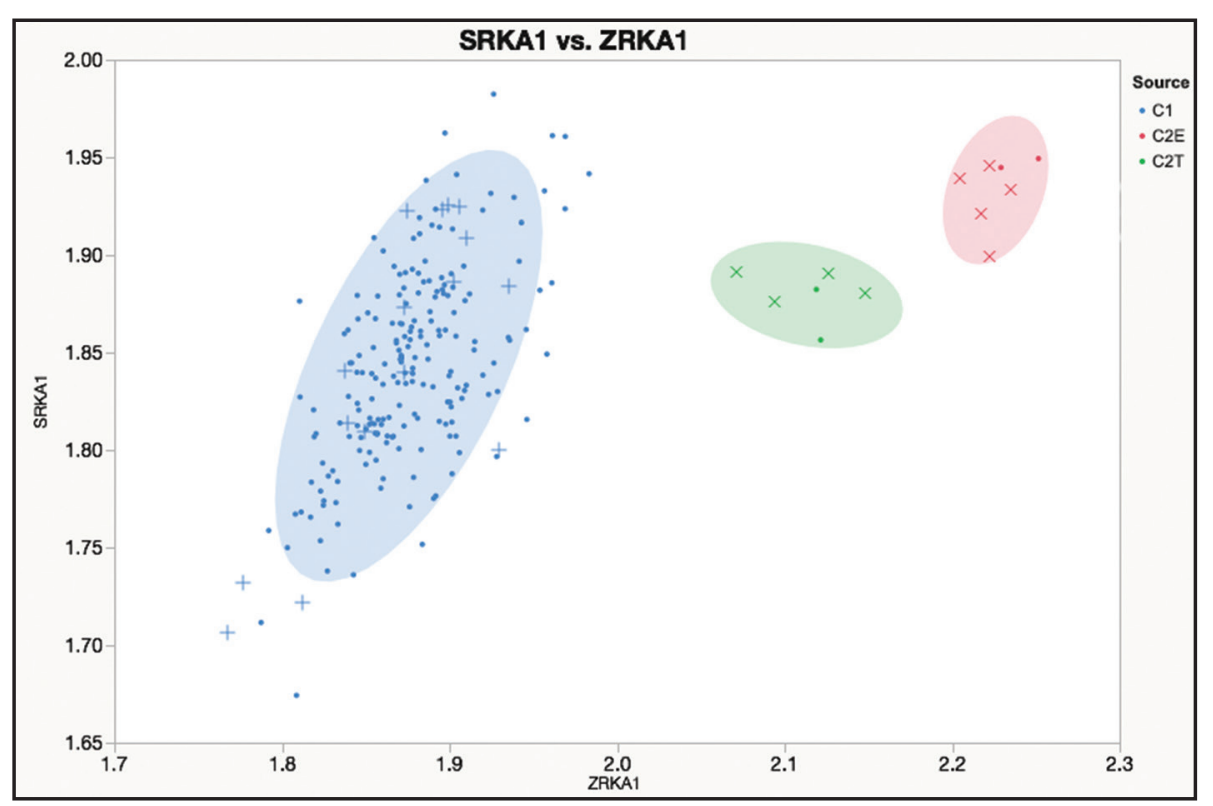

Figure 2. Bivariate plot illustrating archaeological samples (dots) and geological samples. Carpathian 1 sources are blue plus signs $(+)$, Carpathian 2E are red $\mathrm{x}$ 's, and Carpathian 2T are green x's. The results are logged and ellipses represent $90 \%$ confidence intervals. 
elements, the Bruker p-XRF can only accurately measure $\mathrm{Rb}$, thereby making it impossible to further refine the source into subgroups. Therefore, this paper treats Carpathian 1 as one source and the results reflect this approach. Overall, the obsidian sources can be differentiated using a series of bivariate plots and the elements manganese $(\mathrm{Mn})$, iron $(\mathrm{Fe})$, rubidium $(\mathrm{Rb})$, strontium $(\mathrm{Sr})$, yttrium $(\mathrm{Y})$, and zirconium $(\mathrm{Zr})$ (parts-per-million results provided in Supplementary Table 1).

The chipped stone assemblages for the seven Late Neolithic sites (Csökmö-Káposztás Domb, Szeghalom-Várhely, Szentpéterszeg-Kovadomb Szeghalom-Kovácshalom, VésztöMágor, Dévaványa-Réhely-Dülő, and Gyula-Köztisztasági Vállalat) include a total of 611 archaeological specimens. From these assemblages, Dr. Tibor Marton macroscopically identified 223 pieces as obsidian (approximately 36.49\%). Twenty samples were determined to be too small for analysis (for more in-depth discussions about sample size see Davis et al., 1998 and Frahm, 2016) resulting in the analysis of 203 obsidian archaeological samples (approximately 33.22\% of the overall chipped stone tool assemblage) with the Bruker p-XRF (parts-per-million results provided in Supplementary Table 1). The quantity of obsidian varied by site (see Table 2), and with the exception of Dévaványa-Réhelyi-Dülö, obsidian accounted for approximately $20-55 \%$ of any given assemblage. The archaeological compositional results were compared to the geological compositional results using both exploratory and statistical analyses to determine source provenance (see Figure 2).

\section{Results}

The previously identified elements of $\mathrm{Mn}, \mathrm{Fe}, \mathrm{Rb}, \mathrm{Sr}, \mathrm{Y}$, and $\mathrm{Zr}$ were used initially to create bivariate plots to match the archaeological specimens with the geological sources. Bivariate plots with the geological and archaeological materials illustrated the compositional differences between the sources (see Figure 2). A majority of the archaeological specimens analyzed $(n=199)$ were sourced to Carpathian 1, while the remaining four specimens were sourced to Carpathian 2E $(n=2)$ and Carpathian 2T $(n=2$; see Table 3).

Multivariate statistical analyses were employed to further support the groupings identified in the bivariate plots. Principal component analysis (PCA) is often implemented during the statistical analysis of archaeometric results (see Baxter, 1995; 2006). The same six elements (Mn, Fe, Rb, Sr, $\mathrm{Y}$, and $\mathrm{Zr}$ ) used to generate the bivariate plots were utilized during PCA (for similar statistical analyses on data in the region, see Kasztovszky et al., 2014; Prokeš et al., 2015). Approximately $80.5 \%$ of the compositional variation in the archaeological obsidian was accounted for in Principal Component 1 (PC1) and Principal Component 2 (PC2). The same groupings previously identified in the bivariate plots were displayed in the principal component analysis (Figure 3a). As a final measure, Canonical Discriminant Function (CDF; see Glascock, 1992) analysis was also conducted relying on the previously selected elements of $\mathrm{Mn}, \mathrm{Fe}, \mathrm{Rb}, \mathrm{Sr}, \mathrm{Y}$, and $\mathrm{Zr}$. The $\mathrm{CDF}$ results reinforced the previously obtained visual and statistical results, verifying the compositional groupings with 199 specimens originating from Carpathian 1, two specimens originating from Carpathian 2E, and two specimens originating from Carpathian 2T (Figure 3b).

Closer attention to the distribution of Carpathian $2 \mathrm{E}$ and $2 \mathrm{~T}$ archaeological materials revealed that the Carpathian 2E specimens were found at the Tisza sites of SzeghalomKovácshalom and Vésztö-Mágor, while the Carpathian 2T samples were recovered from the Herpály sites of CsökmöKáposztás Domb and Szeghalom-Várhely. These four sites happen to be in relatively close proximity to one another and are, in fact, closer to each other than to any other site in the study. Because the sites are closely located, it stands to reason that distance to the geological locales was not a causal factor for the variation in source exploitation. Rather, the variation may be related to socio-cultural differences between the Herpály and Tisza cultural units.

Based on the predominance of obsidian from Carpathian 1, it appears that the material from this source was more accessible and/or more desirable to inhabitants at sites in the study. Previous compositional studies in the region have noted that the Carpathian 1 source was by far the more heavily exploited source in prehistory (see Burgert et al., 2016; Přichystal, Škrdla, 2014; Prokeš et al., 2015); however, what remains unclear is why the Carpathian $2 \mathrm{E}$ and $2 \mathrm{~T}$ sources were exploited to a lesser extent across the Great Hungarian Plain. Contrary to what is illustrated with Carpathian 1, the overall number of pieces from the other sources suggests that either access was limited to the

Table 3. Provenance of obsidian by site.

\begin{tabular}{lcccc}
\hline \multicolumn{1}{c}{ Site/Material Type } & Carpathian 1 & Carpathian 2E & Carpathian 2T & Total \\
\hline Szentpéterszeg-Kovadomb & 12 & 0 & 0 & 12 \\
Csökmö-Káposztás-Domb & 7 & 0 & 1 & 8 \\
Dévaványa-Réhelyi-dülő & 2 & 0 & 0 & 2 \\
Szeghalom-Kovácshalom & 69 & 1 & 0 & 70 \\
Szeghalom-Várhely & 73 & 0 & 1 & 74 \\
Vésztő-Mágor & 18 & 1 & 0 & 19 \\
Gyula-Köztisztasági Vállalat & 18 & 0 & 0 & 18 \\
\hline Total & $\mathbf{1 9 9}$ & $\mathbf{2}$ & $\mathbf{2}$ & $\mathbf{2 0 3}$ \\
\hline
\end{tabular}


A)

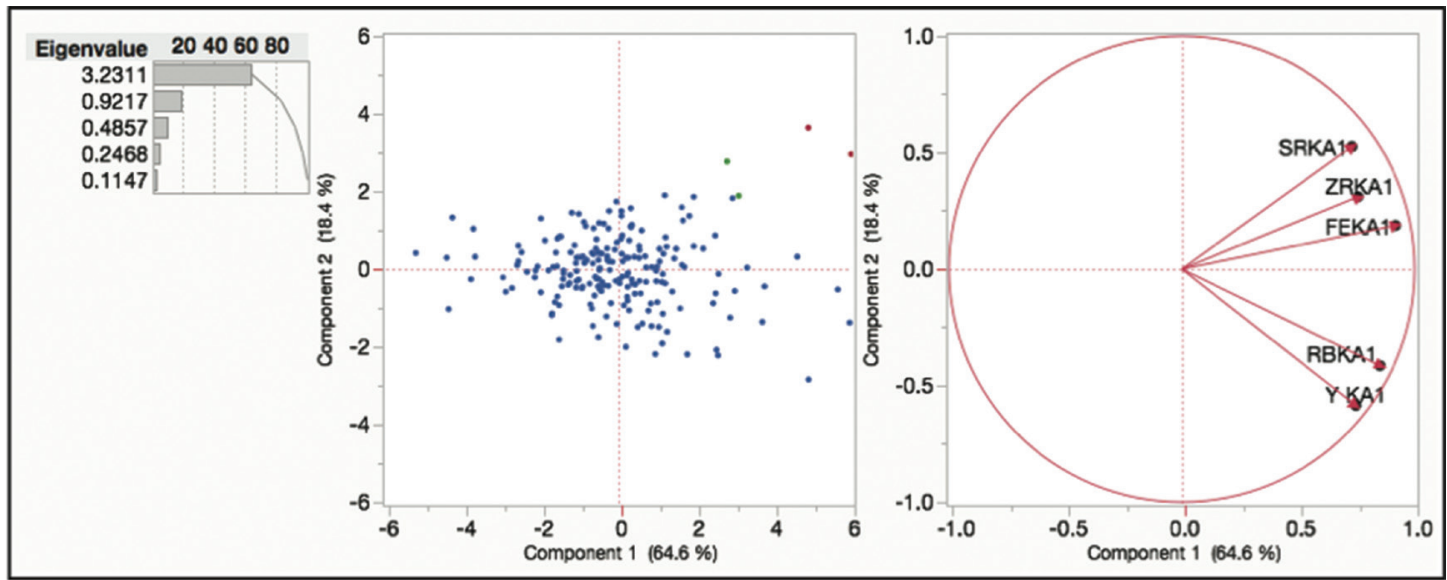

B)

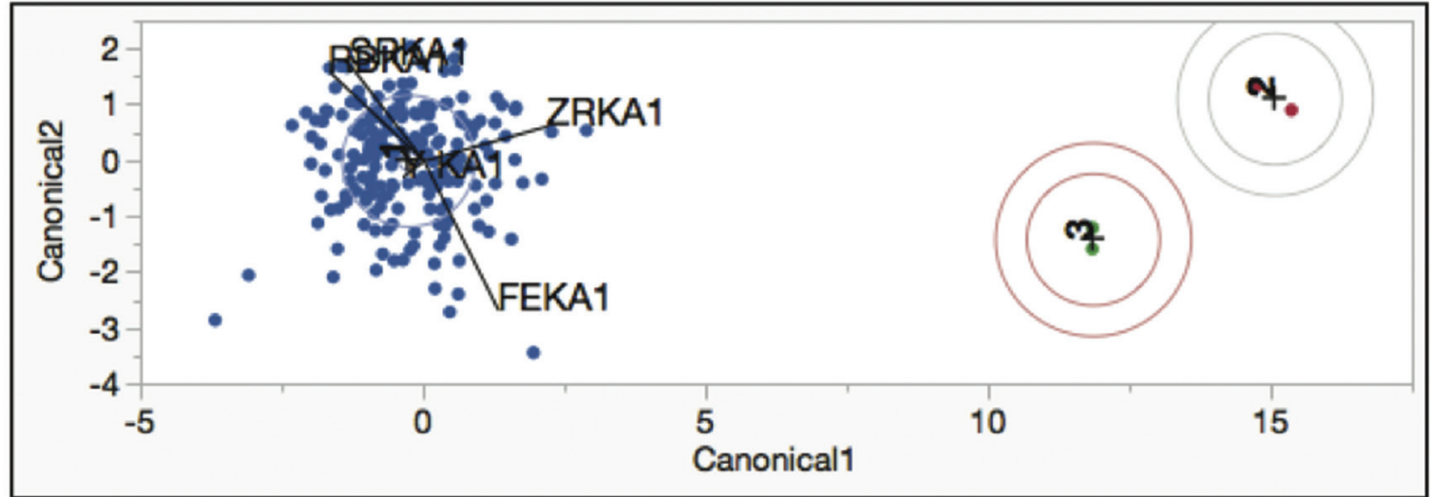

Figure 3. A) Results of the principal component analysis illustrating differences in the archaeological obsidian. Carpathian 1 specimens are blue, Carpathian 2E specimens are red, and Carpathian 2T specimens are green. B) Results of Canonical Discriminant Function analysis illustrating the compositional differences between the archaeological specimens with Carpathian 1 marked as blue, Carpathian 2E marked as red, and the Carpathian 2T marked as green.

Carpathian 2E and 2T sources or the Carpathian 2 sources were less desirable. Notwithstanding, the exclusivity of the Carpathian 2E materials at Tisza sites and Carpathian 2T materials at Herpály sites demonstrates a potential sociocultural preference for or limited access to these secondary sources. This exclusivity combined with the argument of limited access suggests that obsidian might have been a material that was used to actively reinforce sociocultural boundaries during the Late Neolithic.

\section{Conclusions}

Compositional analysis of obsidian materials from Herpály and Tisza sites in this study acts as a starting point for future research on Late Neolithic exploitation, access, exchange, and socio-cultural boundaries through the study of obsidian distribution. Rather than rely on macroscopic analysis of obsidian, by using compositional analysis it is possible to accurately source obsidian to its geological origin. In turn, this presents an opportunity to reconstruct ancient exchange networks and assess how access to those networks and changes in those networks impacted and shaped socio-cultural boundaries. An increased incorporation of compositional analyses in archaeological studies in Eastern Europe has the potential to revolutionize our understanding of past social processes and improve our interpretation of cultural developments.

As discussed in this article, the compositional analysis of 204 obsidian artefacts from seven Late Neolithic sites on the Great Hungarian Plain demonstrated that multiple obsidian geological sources were utilized in prehistory, including Carpathian 1, Carpathian 2E, and Carpathian 2T. While the majority of the archaeological specimens were sourced to Carpathian 1, a small quantity was sourced to Carpathian 2E and Carpathian 2T. Based on the limited number of artefacts from these secondary sources, it does not appear that the Carpathian 2 sources were heavily exploited at this time; however, it is noteworthy that the Carpathian 2E artefacts were only recovered from Tisza sites and the Carpathian $2 \mathrm{~T}$ artefacts were only found at Herpály sites. These results suggest the possibility that exploitation of the secondary obsidian sources was linked to limited access and/or sociocultural preferences. The additional analysis of obsidian artefacts from other Late Neolithic sites across the Great Hungarian Plain will help to test this theory about the sociocultural implications of secondary obsidian source use. Furthermore, these results act as only one line of evidence 
for reconstructing Late Neolithic socio-cultural boundaries. In the next phase of research, the obsidian compositional data will be compared to the ceramic compositional results for materials from the same sites to further illustrate how materials were utilized in the past to shape socio-cultural boundaries.

\section{Acknowledgments}

The results presented in this publication are in large part due to Dr. Katalin Biró at the Hungarian National Museum and Dr. Laure Dussibieux at the Field Museum of Natural History. These researchers provided me access to the geological materials at the Lithotheca and to the Bruker p-XRF instrument at the Field Museum. Without either colleague, this article would not exist. Additionally, I am very grateful for the chipped stone tool analysis conducted by Dr. Tibor Marton at the Hungarian Academy of Sciences. Thank you to the reviewers for their time and feedback - any errors in the article are the sole product of the author. This project was supported by the National Science Foundation (Doctoral Dissertation Improvement Grant - 1312027) and an IIE Student Fulbright Grant to Hungary.

\section{References}

BAČO, P., LEXA, J., BAČOVÁ, Z., KONEČNÝ, P., PÉCSKAY, Z., 2018. Geological Background of the Occurances of Carpathian Volcanic Glass, Mainly Obsidian, in Eastern Slovakia. Archeometriai Mühely, XV/3, $157-166$.

BAXTER, M.J., 1995. Standardization and Transformation in Principal Component Analysis with Applications to Archaeometry. Journal of the Royal Statistical Society, Series C (Applied Statistics), 44/4, 513-527.

BAXTER, M.J., 2006. A Review of Supervised and Unsupervised Pattern Recognition in Archaeometry. Archaeometry, 48, 671-694.

BIAGI, P., DE FRANCESCO, A.M., BOCCI, M., 2007. New Data on the Archaeological Obsidian from the Middle-Late Neolithic and Chalcolithic Sites of the Banat and Transylvania (Romania). In: J.K. Kozłowski, P. Raczky, eds. The Lengyel, Polgár and Related Cultures in the Middle/Late Neolithic in Central Europe. Kraków: Polska Akademia Umiejętności, pp. 309-326.

BIAGI, P., STARNINI, E., 2013. Pre-Balkan Platform Flint in the Early Neolithic Sites of the Carpathian Basin: Its Occurrence and Significance. In: A. Anders, G. Kulcsár, eds. Moments in Time: Papers Presented to Pál Raczky on his $60^{\text {th }}$ Birthday. Budapest: L'Harmattan Kiadó, pp. 47-60.

BIRÓ, K.T., 1984. Distribution of Obsidian from the Carpathian Sources on Central European Palaeolithic and Mesolithic Sites. Acta Archaeologica Carpathica, 23, 5-42.

BIRÓ, K.T., 1987. Chipped Stone Industry of the Linearband Pottery Culture in Hungary. Archaeologica Interregionalis, 240, 131-167.

BIRÓ, K.T., 1998a. Stones, Numbers-History? The Utilization of Lithic Raw Materials in the Middle and Late Neolithic of Hungary. Journal of Anthropological Archaeology, 17, 1-18.

BIRÓ, K.T., 1998b. Lithic Implements and the Circulation of Raw Materials in the Great Hungarian Plain during the Late Neolithic Period. Budapest: Hungarian National Museum.

BIRÓ, K.T., 2006. Carpathian Obsidians: Myth and Reality. In: Proceedings of the 34 $4^{\text {th }}$ International Symposium on Archaeometry, 3-7 May 2004. Zaragoza: Institución Ferando el Católico, 267-278.

BIRÓ, K.T., DOBOSI, V., 1991. Litotheca - Comparative Raw Material Collection of the Hungarian National Museum. Budapest: Magyar Nemzeti Múzeum.
BIRÓ, K.T., DOBOSI, V., SCHLÉDER, ZS., 2000. Litotheca-Comparative Raw Material Collection of the Hungarian National Museum Vol. II. Budapest: Magyar Nemzeti Múzeum.

BRASWELL, G.E., CLARK, J.E., AOYAMA, K.A., MCKILLOP, H.I., GLASCOCK, M.D., 2000. Determining the Geological Provenance of Obsidian Artefacts from the Maya Region: A Test of the Efficacy of Visual Sourcing. Latin American Antiquity, 11, 269-282.

BURGERT, P., P̌̌ICHYSTAL, A., PROKEŠ, L., PETŘÍK, J., HUŠKOVÁ, S., 2017. The Origin and Distribution of Obsidian in Prehistoric Bohemia. Bulgarian e-Journal of Archaeology, 7, 1-15.

CANN, J.R., RENFREW, C., 1964. The Characterization of Obsidian and its Application to the Mediterranean Region. The Prehistoric Society, 30, $111-133$.

CONSTANTINESCU, B., BUGOI, R., SZIKI, G., 2002. Obsidian Provenance Studies of Transylvania's Neolithic Tools Using PIXE, Micro-PIXE, and XRF. Nuclear Instruments and Methods in Physics, Research Section B: Beam Interactions with Materials and Atoms, 189, 373-377.

CONSTANTINESCU, B., CRISTEA-STAN, D., KOVÁCS, I., SZÖKEFALVI-NAGY,Z., 2014. Provenance Studies of Central European Neolithic Obsidians Using External Beam Milli-PIXE Spectroscopy. Nuclear Instruments and Methods in Physics, Research Section B: Beam Interactions with Materials and Atoms, 318, 145-148.

DAVIS, M.K., JACKSON, T.L., SHACKLEY, M.S., TEAGUE, T., HAMPEL, J.H., 1998. Factors Affecting the Energy-Dispersive X-Ray Fluorescence (EDXRF) Analysis of Archaeological Obsidian. In: M.S. Shackley, ed. Archaeological Obsidian Studies: Method and Theory. New York: Plenum, pp. 159-180.

EICHMANN, W.J., 2004. Mesolithic Hunter-Gatherers in the Carpathian Basin and the Spread of Agriculture in Europe. In: Publications from 2004 Hungarian Fulbright Student Conference. Budapest: Hungarian Fulbright Commission, pp. 161-202.

ERDÉLYI-BÁCSKAY, E., 2007. Chipped Stone Tools from the Site PolgárCsőszhalom dülő (Polgár 6. Flat Settlement) - A Preliminary Report. In: J.K. Kozłowski, P. Raczky, eds. The Lengyel, Polgár and Related Cultures in the Middle/Late Neolithic in Central Europe. Kraków: Polska Akademia Umiejętności, pp. 279-285.

FRAHM, E., 2016. Can I Get Chips With That? Sourcing Small Obsidian Artefacts Down to Microdebitage Scales with Portable XRF. Journal of Archaeological Science: Reports, 9, 448-467.

GLASCOCK, M.D., 1992. Neutron Activation Analysis. In: H. Neff, ed. Chemical Characterization of Ceramic Pastes in Archaeology, vol. 7. Madison: Prehistory Press, pp. 11-26.

GLASCOCK, M.D., BARKER, A.W., DRAȘOVEAN, F., 2015. Sourcing Obsidian Artefacts from Archaeological Sites in Banat (Southwest Romania) by X-Ray Fluorescence. Analele Banatului, Arheologie Istorie, 23, 45-50.

KALICZ, N., RACZKY, P., 1987. The Late Neolithic of the Tisza Region: A Survey of Recent Archaeological Research. In: L. Tálas, P. Raczky, eds. The Late Neolithic of the Tisza Region: A Survey of Recent Excavations and their Findings. Budapest-Szolnok: Directorate of the Szolnok County Museums, pp. 11-29.

KASZTOVSZKY, ZS., BIRÓ, K.T., 2006. Fingerprinting Carpathian obsidians by PGAA: First Results on Geological and Archaeological Specimens. In: Proceedings of the $34^{\text {th }}$ International Symposium on Archaeometry, 3-7 May 2004. Zaragoza, Institución Ferando el Católico, pp. 301-308.

KASZTOVSZKY, ZS., BIRÓ, K.T., KIS, Z., 2014. Prompt Gamma Activation Analysis of the Nyírlugos Obsidian Core Depot Find. Journal of Lithic Studies, 1, 151-163.

KASZTOVSZKY, ZS., BIRÓ, K.T., MARKÓ, A., DOBOSI, V., 2008. Cold Neutron Prompt Gamma Activation Analysis: A Non-Destructive Method for Characterization of High Silica Content Chipped Stone Tools and Raw Materials. Archaeometry, 50, 12-29.

KASZTOVSZKY, ZS., BIRÓ, K., NAGY-KORODI, I., SZTÁNCSUJ, S.J., HÁGO, A., SZILÁGYI, V., MARÓTI, B., CONSTANTINESCU, B., BERECKI, S., MIREA, P., 2019. Provenance Study on Prehistoric Obsidian Objects Found in Romania (Eastern Carpathian Basin and its Neighbouring Regions) using Prompt Gamma Activation Analysis. Quaternary International, 510, 76-87.

KERTÉSZ, R., 1994. Late Mesolithic Chipped Stone Industry from the Site of Jásztelek I. In: G. Lőrinczy, ed. A Kökortól a Középkorig. Tanulmányok 
Trogmayer Ottó 60 Születésnapjára. Szeged: Móra Ferenc Múzeum, pp. 23-44.

KERTÉSZ, R., 2003. The Mesolithic: Towards A Production Economy. In: Zs. Visy, ed. Hungarian Archaeology at the Turn of the Millennium. Budapest: Ministry of National Cultural Heritage/Teleki László Foundation, pp. 91-95.

KOVÁCS, K., 2013. Late Neolithic Exchange Networks in the Carpathian Basin. In: A. Anders, G. Kulcsár, eds. Moments in Time: Papers Presented to Pál Raczky on his $60^{\text {th }}$ Birthday. Budapest: L'Harmattan Kiadó, pp. $385-400$.

KOZŁOWSKI, J.K., 2001. Evolution of Lithic Industries of the Eastern Linear Pottery Culture. In: R. Kertész, J. Makkay, eds. From the Mesolithic to the Neolithic. Budapest: Archaeolingua Press, pp. 247-260.

MOHOLY-NAGY, H., 2003. Source Attribution and the Utilization of Obsidian in the Maya Area. Latin American Antiquity, 14, 301-310.

ODDONE, M., MÁRTON, P., BIGAZZI, G., BIRÓ, K.T., 1999. Chemical Characterizations of Carpathian Obsidian Sources by Instrumental and Epithermal Neutron Activation Analysis. Journal of Radioanalytical and Nuclear Chemistry, 240, 147-153.

PERLÈS, C., 1987. Les Industries Lithiques Taillés de Franchthi (Argolide, Grèce). Tome I: Présentation général et industries paléolithique. Excavations at Franchthi Cave. Bloomington, Indianapolis: Indiana University Press.

PERLÈS, C., 1990. Les Industries Lithiques Taillés de Franchthi (Argolide, Grèce). Tome II: Présentation général et industries paléolithique. Excavations at Franchthi Cave, Fascicle 5. Bloomington, Indianapolis: Indiana University Press.

PŘICHYSTAL, A., ŠKRDLA, P., 2014. Kde ležel hlavní zdroj obsidiánu v pravěku střední Evropy? Slovenská archeológia, 62(2), 215-226.

PROKEŠ, L., GALIOVÁ, M.V., HUŠKOVÁ, S., VACULOVIČ, T., HRDLIČKA, A., MASON, A. Z., NEFF, H., PŘICHYSTAL, A., KANICKY, V., 2015. Laser Microsampling and Multivariate Methods in Provenance Studies of Obsidian Artefacts. Chemical Papers, 69(6), 761-778.

RÁCZ, B., 2008. Pattintott Kőeszköz-nyersanyagok Felhasználásának Előzetes Eredményei a Paleolitikumban a Mai Kárpátalja Területén. Archeometriai Mühely, 2008(2), 47-54.

RÁCZ, B., 2012. Kárpátaljai Obszidiánok: Szakirodalmi Adatok és Terepi Tapasztalatok. In: A. Kreiter, Á. Pető, B. Tugya, eds. Environmenthuman-culture. Dialogue between Applied Sciences and Archaeology. Budapest: Hungarian National Museum, National Cultural Heritage Protection Centre, pp. 353-362.

RÁCZ, B., SZAKMÁNY, GY., BIRÓ, K., 2016. Contribution to the Cognizance of Raw Materials and Raw Material Regions of the Transcarpathian Palaeolithic. Acta Archaeologica Academiae Scientiarum Hungaricae, 67, 209-230.

RENFREW, C., CANN, J.R., DIXON, J.E., 1965. Obsidian in the Aegean. Annual of the British School of Archaeology at Athens, 60, 225-247.

RIEBE, D.J., 2016. Interaction and Socio-Cultural Boundaries During the Late Neolithic on the Great Hungarian Plain. Unpublished thesis (PhD), University of Illinois at Chicago.
ROSANIA, C.N., BARKER, A.W., 2009. Obsidian Procurement at Pecica Şanțul Mare, Romania. Muse, 43, 19-30.

ROSANIA, C.N., BOULANGER, M.T., BIRÓ, K.T., RYZHOV, S., TRNKA, G., GLASCOCK, M.D., 2008. Revisiting Carpathian Obsidian. Antiquity, 82, 318.

STARNINI, E., 1994. Typological and Technological Analysis of the Körös Culture Chipped, Polished and Ground Stone Assemblages of MéhtelekNádas (North-eastern Hungary). Atti della Societá per la Preistoria e Protostoria del Friuli Venezia- Giulia, 8, 29-96.

STARNINI, E., SZAKMÁNY, GY., 1998. The Lithic Industry of the Neolithic Sites of Szarvas and Endröd (South-Eastern Hungary): Techno-Typological and Archaeometrical Aspects. Acta Archaeologica Academiae Scientiarum Hungaricae, 50, 279-342.

STARNINI, E., VOYTEK, B., 2012. "Post" Transformation: Preliminary Research into the Organization of Technology during the Neolithic. Interdisciplinaria Archaeologica: Natural Sciences in Archaeology, 3(1), 47-63.

STARNINI, E., VOYTEK, B.A., HORVÁTH, F., 2007. Preliminary Results of the Multidisciplinary Study of the Chipped Stone Assemblage from the Tisza Culture Site of Tell Gorzsa (Hungary). In: J.K. Kozłowski, P. Raczky, eds. The Lengyel, Polgár and Related Cultures in the Middle/Late Neolithic in Central Europe. Kraków: Polska Akademia Umiejętności, 269-278.

TÁLAS, L., RACZKY, P., 1987. The Late Neolithic in the Tisza Region. Budapest, Szolnok: Directorate of the Szolnok County Museums.

TORRENCE, R., 1986. Production and Exchange of Stone Tools: Prehistoric Obsidian in the Aegean. Cambridge: Cambridge University Press.

TYKOT, R.H., 2002a. Chemical Fingerprinting and Source Tracing of Obsidian: The Central Mediterranean Trade in Black Gold. Accounts of Chemical Research, 35, 618-627.

TYKOT, R.H., 2002b. Geochemical Analysis of Obsidian and the Reconstruction of Trade Mechanisms in the Early Neolithic of the Western Mediterranean. In: J. Jakes, ed. Archaeological Chemistry, Materials, Methods, and Meaning. ACS Symposium Series, 831. Washington, DC: American Chemical Society, pp. 169-184.

VOYTEK, B., 1986. Analysis of Lithic Raw Materials from Sites in Eastern Yugoslavia. In: K. Biró, ed. Proceedings of the $1^{\text {st }}$ International Conference on Prehistoric Flint Mining and Lithic Raw Material Identification in the Carpathian Basin. Budapest, Sümeg, 20-22 May, 1986. Budapest: Hungarian National Museum, pp. 287-295.

WILLIAMS, O., NANDRIS, J., 1977. The Hungarian and Slovak Sources of Archaeological Obsidian: An Interim Report on Further Fieldwork, with a Note on Tektites. Journal of Archaeological Science, 4, 207-219.

WILlIAMS THORPE, O.W., 1978. A Study of Obsidian in Prehistoric Central and Eastern Europe, and its Trace Element Characterization. Unpublished thesis (PhD), University of Bradford.

WILLIAMS-THORPE, O., WARREN, S.E., NANDRIS, J., 1984. The Distribution and Provenance of Archaeological Obsidian in Central and Eastern Europe. Journal of Archaeological Science, 11, 183-212. 